\title{
Opinions Regarding the University Students of Humanity's Problems and Their Solutions
}

\author{
Füsun Gülderen Alacapinar
}

Faculty of Education, Necmettin Erbakan University, Turkey

\begin{abstract}
Copyright $\subseteq 2017$ by authors, all rights reserved. Authors agree that this article remains permanently open access under
\end{abstract} the terms of the Creative Commons Attribution License 4.0 International License

\begin{abstract}
Problem statement: There are many problems that humanity is facing today and has to solve. These problems can be gathered under several headings. Most important ones among these problems can be listed as follows: Threat of nuclear war; human being pushed into solitude and repugnancy; disturbance of natural balance; population growth; black holes swallowing our planet; exhaustion of underground and surface resources; unfair income distribution both internationally and within countries; and lack of affection. Purpose of Study: What is the most important problem in the world according to university students? What kind of ideas make university students find that problem as the most important one? Methods: The qualitative method used was soliciting the written opinion of university students anonymously. Findings and Results: University students regard lack of affection as the most important problem that humanity is facing today. They argue that this lack of affection may be the root cause of other problems and say when affection reigns; other problems can be solved more easily. Other problems that follow the most important one are as follows: Wars, disturbance of natural balance and pollution; others (ignorance; selfishness, lack of empathy, poor communication, mistrust, intolerance, degeneration in mind and heart, parental clashes, information pollution, distorted urbanization); human being pushed into solitude; exhaustion of natural resources; unfair income distribution; population growth and black holes swallowing the planet. Conclusions and Recommendations: On the basis of findings, one can say that university students are aware of problems that humanity is facing. In established industrial and information societies individuals are left alone. This may feed the feeling of solitude and the feeling, in turn, may lead to lack of affection. During focus group meetings university students addressed these issues and emphasized that lovelessness is the malady of our time. They added that no other problem can be solved without solving this one first.
\end{abstract}

Keywords Mankind's Problems, University Students, Solution Proposals

\section{Introduction}

There are many problems that humanity is facing today and has to solve. These problems can be gathered under several headings. Most important ones among these problems can be listed as follows: Threat of nuclear war; human being pushed into solitude and repugnancy; disturbance of natural balance; population growth; black holes swallowing our planet; exhaustion of underground and surface resources; unfair income distribution both internationally and within countries; and lack of affection [11]. One can either add new problems to or shorten the list. Each educated person can notice these problems no matter how they are approached to. An educated person is expected to solve these problems. Raising individuals who are aware of existing problems, coming up with solutions and actually solving them is a desired outcome recognized by all education systems.

For a person to solve a problem, he/she must be aware of it at first, regard it as a problem, conscious of dangers that a defined problem may give rise to and willing to take action for its solution. Some of these characteristics are related to cognitive and others related to affective and psychomotor domains. In general, affective characteristics are dominant in getting aware of, regarding as a problem, developing interest in and willingness to solve.

There is a meaningful relationship between affective characteristics and success [3,11]. Indeed, affective characteristics may be highly influential in solving many problems. As observed in recent Gezi demonstrations, variables such as coercion, imposing undesired ways of life from without and direct interventions to personal mode of life may give rise to unexpected reactions. Variables giving rise to such reactions may at large derive from affective domain. So, affective domain is important since many reactions start out from affection $[4,5,6,7,8,9]$.

There may be some values that an individual or a society as a whole upholds, is fully committed to and ready to make 
sacrifices for. These values may not show great variances in form from society to society. For instance, love for the country, nation, parents, children, nature or God may be observed in all settled societies. In addition, the following values may in general be adopted and upheld by individuals and societies: righteousness, being assertive in defending one's rights, respectfulness, honesty, tolerance, helpfulness, reliability, trustworthiness, industriousness and avoidance of selfishness, parasitism, tyranny, oppression, insulting, killing, stealing, etc. [1,2].

While values mentioned above appear to have the same meaning in all societies, what is attributed to them and affective dimensions may differ with respect to individual societies and time. In other words, one or few of these values may come to the fore among others at specific times and for specific individuals. Moreover, a value which is utterly important for a society and an individual at a specific time may not be so at another time for the same society and individual. In this context, it can be said that values may change with respect to time, society and prevailing conditions $[10,15,16]$.

Since any value has its ethical and moral connotations they are also in close relationship with philosophy. Each philosophical opinion has its different dominant values. For example, while some philosophical views uphold rational action others may focus on various other points such as being moderate, avoiding extremes, confirming to traditions, fulfilment of established duties, engaging in activities to the benefit of all, life in harmony with the nature, enjoyment of life, suffering pain or not to exploit any one [1, $2,12]$.

A significant part of achievements in an education system is related to values. This means, a person educated must be equipped with ethical and moral behaviour. It is one of the duties of the education system to raise individuals who adopt, implement, advocate and further develop some of the values mentioned above. In this context, students attending university are expected to be sensitive to existing problems and to make efforts for their solution. In other words, an educated person must be the one who is aware of and trying to find solutions to major problems around.

Once ethical and moral values attached importance by university students are identified, they may be given priority in programmes. It is one of the requirements of education that persons are imparted in patterns of behaviour that are considered as desirable. Also, while programmes are developed, it is necessary to take into account the needs of individual concerned. In this context, values that a programme must include can be identified by conducting a needs analysis. A programme geared to achievements identified this way may be more effective from the stand of students.

What is the most important problem in the world according to university students? What kind of ideas make university students find that problem as the most important one?

1. What is the most important problem in the world according to university students?

2. Does the problem that is found as most important vary with respect to academic departments and gender?

3. What ideas lead students to consider this or that problem the most important one?

4. What do students suggest as solutions to problems that they consider most important?

\section{Method}

\subsection{Research Design}

In this survey, the anonymous opinion soliciting technique of qualitative survey methodology and the screening technique quantitative-descriptive methodology are used in combination [13]. In the survey, students in education faculties were asked to give their written opinions on questions "What is the most important problem that humanity faces today?", "Why?" and "What must be done to solve this problem?" Opinions of three experts were solicited as to the relevance and validity of these questions. A correlation of .78 was found in these opinions, which is taken as confirmation of the relevance and validity of questions. Then, data collected in written form were examined by using "content analysis" and "data reduction" methods. For this, responses given by each student are divided into categories in terms of nouns, adjectives and pronouns to see logical consistency among them.

In order to check the internal reliability and consistency of the survey, relations and characteristics of meaning between responses given to questions and opinions and values were examined by experts, and a correlation of .75 was found among the opinions of these experts. This correlation is taken as reliability coefficient. As for external reliability, information collected was openly presented to the working group and stored to be given to researches when asked.

There was no universe and sample definition in the survey. An appropriate status working group was selected instead. The survey covered 267 students attending to and taking education courses in health and nursing, fine arts, mathematics, chemistry, physics and Turkish Language and Literature departments of the Faculty of Education. Having this working group made it easier and quicker to reach data. Responses given by students were recorded and analysed. Grammar and other language errors in students' written responses were corrected by taking the consent of students [14].

\section{Findings and Results}

\subsection{Working Group}

Table 1. below gives the distribution of students enrolled to Ahmet Keleşoğlu Education Faculty in Necmettin Erbakan University who are covered by the survey. 
Table I. Distribution of Students by Departments and Sex

\begin{tabular}{|c|c|c|c|c|c|c|c|}
\hline \multirow{2}{*}{ Department } & \multicolumn{2}{|c|}{ Students } & \multicolumn{2}{|c|}{ Female } & \multicolumn{2}{|c|}{ Male } & \multirow{2}{*}{$\mathrm{t}$} \\
\hline & $\mathrm{n}$ & $\%$ & $\mathrm{n}$ & $\%$ & $\mathrm{n}$ & $\%$ & \\
\hline Health and Nursing & 60 & 22 & 52 & 30 & 8 & 07 & \\
\hline Fine Arts & 40 & 15 & 25 & 14 & 15 & 16 & \\
\hline Mathematics & 43 & 17 & 15 & 34 & 28 & 53 & \\
\hline Chemistry & 36 & 13 & 16 & 44 & 20 & 56 & \\
\hline Physics & 30 & 11 & 10 & 33 & 20 & 67 & \\
\hline $\begin{array}{l}\text { Turkish Language } \\
\text { and Literature }\end{array}$ & 58 & 22 & 38 & 22 & 20 & 24 & \\
\hline Total & 267 & 100 & 175 & 66 & 92 & 34 & Female and Male $=6.4$ \\
\hline
\end{tabular}

Table 2. Most Important Problem that Humanity is Facing According to Students

\begin{tabular}{|c|c|c|c|}
\hline Problems & Frequency & Percentage & $\mathrm{t}$ \\
\hline Affection, lack of affection & 156 & 36 & $\begin{array}{l}\text { Affection and war }=3.2 \\
\text { Affection-Natural } \\
\text { balance }=4.8 \\
\text { Affection-Other=5 } \\
\text { Affection-Underground =6 } \\
\text { Affection-Solitude }=6 \\
\text { Affection-Income }=6.4 \\
\text { Affection- } \text { Population }=6.4 \\
\text { Affection-Black hole }=6.8\end{array}$ \\
\hline Nuclear war, armed conflicts & 86 & 20 & $\begin{array}{l}\text { Wars-Underground }=2.8 \\
\text { Wars-Solitude }=2.8 \\
\text { Wars-Income }=3.2 \\
\text { Wars-Population }=3.2 \\
\text { Wars-Black hole }=3.6\end{array}$ \\
\hline $\begin{array}{l}\text { Disturbance of the natural balance (pollution) } \\
\text { Other (ignorance; selfishness, lack of empathy, poor } \\
\text { communication, mistrust, intolerance, degeneration in mind and } \\
\text { heart, parental clashes, information pollution, distorted } \\
\text { urbanization) }\end{array}$ & 54 & 12 & Natural-Black hole $=2$ \\
\hline Exhaustion of underground and surface resources & 26 & 6 & \\
\hline $\begin{array}{l}\text { Human being pushed into solitude and repugnancy (solitude, } \\
\text { having no one, insensitivity, otherization, instrumentalism) }\end{array}$ & 25 & 6 & \\
\hline Unfair income distribution & 17 & 4 & \\
\hline Population growth & 16 & 3 & \\
\hline Swallowing of the planet by black holes & 11 & 2 & \\
\hline TOTAL & 438 & 1 & \\
\hline
\end{tabular}

As can be seen in Table 1, 60 out of 267 students (22\%) are in health and nursing, $40(15 \%)$ in fine arts; $109(41 \%)$ in mathematics, physics and chemistry and $58(22 \%)$ in Turkish language and literature department. Of 60 students in health and nursing department $52(30 \%)$ are females and $8(07 \%)$ are males. The gender distribution of students in other departments is as follows: fine arts: 40 students, 25 females $(14 \%)$ and $15(16 \%)$ males; mathematics, chemistry and physics: 109 students, 41 (38\%) females and 68 (62\%) males; Turkish language and literature: 58 students, 38 females (22\%) and 20 males (24\%). The gender distribution of 267 students shows a significant variance where female students in three departments outnumber males. $t$ test is applied to see whether there is significant difference in the distribution of students to departments and their distribution in the working group. It can be said that the number of students from different departments included in the working group is consistent with students' percentage distribution in these departments. The gender distribution of students in health and nursing department shows statistically significant difference where the number of females in this department is significantly higher than males. The difference in gender 
distribution of students in other departments is found as statistically insignificant.

\subsection{First Sub-problem}

Data related to the most important problem that humanity is facing according to university students are given in Table 2

As can be seen in Table 2, there were 438 responses given by 267 students. According to responses given, 36\% of students (from 156 responses) regard affection and lack of affection as the most important problem that humanity is facing today. $20 \%$ (86 responses) refer to nuclear war, $12 \%$ (54 responses) to the disturbance of natural balance, $11 \%$ (47 responses) to other problems, 6\% to the exhaustion of natural resources and being pushed into solitude and repugnancy (26 and 25 responses, respectively), 4\% (17 responses) to unfair income distribution, $3 \%$ to population growth (16 responses) and 2\% to black holes swallowing the planet (11 responses). T test was applied to see whether there is significant difference in percentage distribution of problems. There is statistically significant difference between affection on the one side and eight other variables on the other: nuclear war, exhaustion of natural resources, human beings in solitude, unfair income distribution, population growth and the planet swallowed by black holes. Leaving the variables affection and nuclear war aside, differences among the remaining 7 variables are statistically insignificant. On the basis of this information, it can be said that affection and nuclear war are the two most important problems for students attending these departments of the faculty of education.

\section{Second Sub-problem}

Distribution by departments of responses given by university students to the question on the most important problem that humanity is facing today is presented in Table 3.

Chi-square test is applied to see whether there is significant relationship between the department that students are enrolled to and their opinion of the most important problem. The chi-square value obtained is 46.688 . The value in the table on the basis of .05 significance level and 40 degree of freedom is 55.76'dir. Since calculated value is smaller than what is read from the table, no significant relationship could be found between departments and responses of students. On the basis of this, it can be said that students' opinions on respective problems do not change significantly with respect to departments.

\subsection{Third Sub-problem}

Gender distribution of responses given by university students to the question on the most important problem in the world is presented in Table 4.

Table 3. Distribution of Problems by Departments

\begin{tabular}{|c|c|c|c|c|c|c|c|c|c|c|}
\hline & $\begin{array}{l}\text { Affection } \\
\text { lack of } \\
\text { affection }\end{array}$ & $\begin{array}{l}\text { Disturbance } \\
\text { of the natural } \\
\text { balance }\end{array}$ & $\begin{array}{l}\text { Exhaustion of } \\
\text { underground } \\
\text { and surface } \\
\text { resources }\end{array}$ & $\begin{array}{l}\text { Unfair } \\
\text { income } \\
\text { distribution }\end{array}$ & $\begin{array}{l}\text { Nuclear } \\
\text { War } \\
\text { (War) }\end{array}$ & $\begin{array}{c}\text { Population } \\
\text { growth }\end{array}$ & $\begin{array}{c}\text { Swallowing } \\
\text { of the planet } \\
\text { by black } \\
\text { holes }\end{array}$ & $\begin{array}{l}\text { Human being } \\
\text { pushed into } \\
\text { solitude and } \\
\text { repugnancy }\end{array}$ & Other & TOTAL \\
\hline $\begin{array}{l}\text { Health- } \\
\text { Nursing }\end{array}$ & 49 & 15 & 9 & 2 & 22 & 2 & 3 & 11 & 18 & 131 \\
\hline Fine Arts & 25 & 5 & 4 & 4 & 3 & 1 & 1 & 2 & 4 & 49 \\
\hline Physics & 14 & 7 & 3 & 2 & 14 & 3 & 3 & 1 & 10 & 57 \\
\hline Chemistry & 14 & 6 & 5 & 2 & 14 & 4 & 2 & 2 & 2 & 51 \\
\hline $\begin{array}{l}\text { Mathematics } \\
\text { Turkish }\end{array}$ & 22 & 8 & 3 & 2 & 14 & 4 & 1 & 2 & 3 & 59 \\
\hline $\begin{array}{l}\text { Language } \\
\text { and literature }\end{array}$ & 32 & 13 & 2 & 5 & 19 & 2 & 1 & 7 & 10 & 91 \\
\hline TOTAL & 156 & 54 & 26 & 17 & 86 & 16 & 11 & 25 & 47 & 438 \\
\hline
\end{tabular}

Table 4. Distribution of Problems by Sex

\begin{tabular}{|c|c|c|c|c|c|c|c|c|c|c|}
\hline & $\begin{array}{l}\text { Affection-lack } \\
\text { of affection }\end{array}$ & $\begin{array}{l}\text { Disturbance } \\
\text { of the natural } \\
\text { balance }\end{array}$ & $\begin{array}{c}\text { Exhaustion of } \\
\text { underground } \\
\text { and surface } \\
\text { resources }\end{array}$ & $\begin{array}{c}\text { Unfair } \\
\text { income } \\
\text { distribution }\end{array}$ & $\begin{array}{l}\text { Nuclear } \\
\text { War } \\
\text { (War) }\end{array}$ & $\begin{array}{l}\text { Population } \\
\text { growth }\end{array}$ & $\begin{array}{l}\text { Swallowing } \\
\text { of the planet } \\
\text { by black } \\
\text { holes }\end{array}$ & $\begin{array}{l}\text { Human } \\
\text { being } \\
\text { pushed into } \\
\text { solitude }\end{array}$ & Other & TOTAL \\
\hline Female & 83 & 32 & 11 & 12 & 54 & 10 & 2 & 13 & 23 & 240 \\
\hline Male & 73 & 22 & 15 & 5 & 32 & 6 & 9 & 12 & 24 & 198 \\
\hline TOTAL & 156 & 54 & 26 & 17 & 86 & 16 & 11 & 25 & 47 & 438 \\
\hline
\end{tabular}


Chi-square test was used to check whether there is any significant relationship between gender status and opinions about the most important problem. The chi-square value obtained is 13.229. The value in the table on the basis of .05 significance level and 8 degree of freedom is 15.51 . Since calculated value is smaller than what is read from the table, no significant relationship could be found between sex and responses of students. On the basis of this, it can be said that students' opinions on respective problems do not change significantly with respect to their gender.

\subsection{Fourth Sub-problem}

Opinions of students regarding problems in the world is obtained through the techniques of semi-structured focus group interviews and written statements. Some statements are given below after some corrections were made with their approval and in a way not to disturb their original version. Focus group interviews were conducted with 3 male and 3 female students randomly selected from among. The opinions of students on why they attach importance to affection and war are presented below.

In your opinion, what is the most important problem and why?

Male 1: The most important problem is about affection. We are living in a world without affection. All is built upon selfish interests. The society is composed of selfish individuals, all looking for more and more.

Male 2: Friendship is left back in fables. We left it back in our hometowns and villages. It used to exist during the time of my parents and grandparents. It is as if an image dating back to the past. Individual is all alone in masses. You can't trust anyone because there is no affection. Everybody is talking about it, but there is no such thing now.

Male 3: Nowadays friendship, helping others, tolerance and affection are all regarded as pieces of foolishness. These are things I frequently hear from my acquaintances: "Look after your own interests; you are the captain navigating your ship. Don't you ever have attachment or commitment to anyone else. It is weakness. They'd just abuse you..." Then we have a society devoid of any affection. You can expect all kinds of maladies in a society like this.

Female 1: It is affection according to me. Almost no problem arises if people really like each other. It is easily settled even if it does. Lack of affection, hatred, enmity and bigotry bring along otherization.

Female 2:I think affection or lack of it is the most important problem that we face today. A generation without any feeling of action is here now and we are moving towards another which would be even worse. We are all after our personal all interests. This means destroying the nature and other people, using them only as our apparatus. Using people and the nature as mere instruments may be the root cause of all problems.

Female 3: in my opinion too it is affection and wars that derive from the absence of the former. I mean the root cause of wars is lack of affection. People and nations without affection uphold their self-interests all the time. They always place themselves at the centre and manipulate others in line with their interests. I think the most important cause of wars is the dissatisfaction of those who govern countries.

\section{Fifth Sub-problem}

Students' opinions about possible solutions were obtained through semi-structured focus group interviews and written statements. Some statements are given below after some corrections were made with their approval and in a way not to disturb their original version. Some statements are given below after some corrections were made with their approval and in a way not to disturb their original version. Focus group interviews were conducted with 3 male and 3 female students randomly selected from among.

Male 1: Parents should accord their children unconditional love without expecting anything in return. They should raise them in an environment of affection. An individual raised in such environments cannot develop negative feelings against other people and all living creatures, cannot usurp their rights. This precludes wars and there is no disturbance to natural balance. Since affection is at the root of everything, all other problems can be solved if it exists.

Male 2: I agree with my friend, but parental affection is not enough. The state and the nation must also love and respect each other. Parents do love their children bat this love is not enough in itself. The state does not love its citizen. Ideas, feelings, all contaminated. Everything is built upon self-interest; on lies and deception. The perception is that you should turn the corner, no matter how you turn or the captain should save his ship. If it is so at micro level, then international relations too are built on the same. Does not the saying in the British Parliament confirm this: "there is no persistent friendship or enmity among nations, there is only respective interests." Just look at wars: all arise out of seeking self-interest. The winner is always right. Even the United Nations operate and take decisions in line with the interests of five states. If there were affection at the very beginning, this organization would work on the basis of such things as equality, fraternity, justice, rights, virtue and honesty. Does the United Nations seem to be upholding these? No. These are just "business as usual". What actually happens is what five big states say. We have the cases of Iraq, Uyghur Autonomous Region, Libya, Tunisia, Egypt, Ukraine, Crimea etc. In which of these cases can you find justice, fraternity, rights and rule of law? Once you grant these five big states this authority injustice, unfairness and lawlessness begin. There is discrimination there and there is no place for affection where there is discrimination. The world cannot enjoy peace with such organizations since there is not affection but self-interest in their basis. All nations, states and peoples must have equal rights in the United Nations. Nobody no State must have the right to veto. A world human and nature rights court must be established 
on the basis of modern science, arts and thought that would adopt the principles of the rule of law and justice and defend human and nature rights. Each country must have its domestic court under the one mentioned above and some members of these national courts must be selected by the United Nations for a five -year term in office there. Decisions taken by these courts must be strictly enforced. Decisions of domestic must be examined and finalized by a United Nations Higher Court under the UN General Assembly. These decisions must be definitive and each State must strictly comply with. This system may prevent wars.

Male 3: I think there is nothing left to say... It is right and I think this way too.

Female 1: What else can I add? This friend told just what things should be. These problems will find their solutions ultimately, if not we shall disappear. I think the humanity cannot yet see the most important problem. These black holes, they are going to swallow us. Then there will be no problem at all since everything will be finished.

Female 2. Affection is important; I can't see it in my environments, because there is no human being left. Each says to another I'll like you if you do this or that. I mean liking is made conditional upon something. Would you call it affection? So, present conditions must be done away with.

Female 3: I think love is missing in this world of today. This is the root cause of all problems in my opinion. How can it be solved? It can be solved if you embrace all, meet the needs of needy people, be just, provide them opportunities, according to their talents and capacity, to climb to highest positions, give them jobs, food, housing and a safe environment to live in.

\section{Conclusions and Recommendations}

The absence of any significant relationship between students' opinions on problems and their education departments and gender may be explained by such factors as almost identical levels of education of university students in Konya, their common background of coming from similar small towns and rural settlements and also common cultural values. Further, problems they face in their environments may also be similar. Finally, they watch the same films and programmes on screens that may have contributed to this outcome.

A large majority of students listed affection, wars, disturbance to natural balance and exhaustion of natural resources as most important problems. This is a natural and expected outcome since they frequently come across news and programmes on these issues in written and visual media. There are also scientific studies on the same issues. Again a large majority of students say they watch documentaries on TV and these are the issues mostly addressed by documentaries. The disturbance to natural balance and exhaustion of natural resources may be marked as most important problems under the impact of these programmes. Also, many of them come from rural settlements and small
Anatolian towns to study in a big metropolitan city like Konya, where they can observe air, soil and water pollution. In other words they may be learning by experiencing and observing. Indeed, this point is confirmed by the statement "I directly observe pollution and exhaustion of resources. Further I learn about it from documentaries."

As for affection and lack of it, affection bears a great importance in our society. Love for parents, siblings, nation, country and God is intensive and thus painful in societies that experience rather quick transitions from nomadic to settled and then to industrial and information society. Rapidly changing values, dissolution of communities and rural to urban migration may make the lack of affection more pronounced. The mode of life in villages and rural environments based on intimate friendships is almost non-existent in urban centres. When a large majority of students coming from rural areas or small towns arrive and live in big cities as university students they may be missing warm relation that they left back in their settlements. The find human relations around as based on self-interest As a matter of fact students made statements such as "Friendship is left back in fables. We left it back in our hometowns and villages. It used to exist during the time of my parents and grandparents" or "Individual is all alone in masses. You can't trust anyone because there is no affection. We are living in a world without affection. All is built upon selfish interests. The society is composed of selfish individuals, all looking for more and more" or "Individual is all alone in masses. You can't trust anyone because there is no affection. Lack of affection, hatred, enmity and bigotry bring along otherization."

Seeing nuclear war as the second most important problem can be attributed to recent cases of warfare and TV programmes and documentaries on armed conflicts. "I grasped how war can be so destructive after watching a documentary on the bombing of Hiroshima and Nagasaki. Now they got hydrogen and neutron bombs which are even more destructive. Can you imagine; buildings, cities will remain as they were but all living species will be gone. I can't attribute any rationality to the minds of these people. For God's sake: There may be no life on earth for 300 to 500 years if all bombs are used!" These statements clearly points out to awareness about the danger of a nuclear war.

Students argue that affection must be the dominant in families, societies, states and international relations for the solution of these problems. "Parents should accord their children unconditional love without expecting anything in return"... "But parental affection is not enough. The state and the nation must also love and respect each other." Students also stress that the structure of the United Nations must change in order to eliminate the risk of war in international relations. Related ideas are as follows: "Repealing of the right to veto granted to 5 States; each state having equal rights with others in the United Nations; establishment of human and nature rights courts in each country that are to work under the United Nations Higher Court; embracing all, meeting the needs of needy people, 
being just, providing people opportunities, according to their talents and capacity, to climb to highest positions, giving them jobs, food, housing and a safe environment to live in.." These are stated as a way of solution to problems that humanity is facing now.

The study can be replicated in other universities and countries. Data can be gathered from a wider working group by employing different research techniques. There may be focus on students attending primary and secondary schools. The research topic may be the influence on this variable of various factors including education philosophy, what is taught in history courses, values embodied in traditions and customs, economic status, political philosophy of states and systems of belief.

\section{REFERENCES}

[1] Akarsu, B. (1965). Teachings in ethics I. İstanbul Üniversitesi, Faculty of Literature

[2] Akarsu, B. (1968). Teachings in ethics II. İstanbul Üniversitesi, Faculty of Literature

[3] Bloom, B.S. (1974). Human characteristics and school learning. New York.

[4] Buscaglia, L. (1986a). Love (Translated by. Nejat Ebcioğlu). İstanbul: İnkılap Publishers.
[5] Buscaglia, L. (1986b). Living, loving, learning (Translated by Nesrin Kasap). İstanbul: İnk1lap Publishers.

[6] Buscaglia, L. (1987a). Loving each other (Translated by Nejat Ebecioğlu). 1987. İstanbul: İnkılap Publishers.

[7] Buscaglia, L. (1987b). Kişilik (Çev. Nejat Ebcioğlu). 1987. İstanbul; İnkılap Publishers.

[8] Buscaglia, L. (1987c). Bus 9 to paradise (Translated by. Belk1s Çorakç1). 1987. İstanbul: İnkılap Publishers.

[9] Fromm, E. (1985). The art of loving. (Translated by. Işıtan Gündüz). 1985. İstanbul: İnk1lap Publishers.

[10] Güvenç, B.(1972). Human being and culture: Introduction to Anthropology. Ankara: Hacettepe Publishers.

[11] Sönmez, V. (2012). Love in education environments. Ankara: Anı Publishers.

[12] Sönmez, V. (2013). Philosophy of science. Ankara: An1 Publishers.

[13] Sönmez,V\& Alacapınar, F.G. (2014). Illustrated scientific research methods. (3rd Edition) Memories Publishing, Ankara .

[14] Merriam, S. B. (2009). Qualitative research. A guide to design \& implementation. San Fransisco: Jossey Bass.

[15] Yörükoğlu, A. (1983). Family and the child in a changing society. Ankara: Bilgi Publishers.

[16] Yörükoğlu, A. (1986). Spiritual health in children. 1986. Ankara: Bilgi Publishers 